\title{
RELATIONSHIP OF KNOWLEDGE AND ATTITUDES OF PREGNANT WOMEN ON THE INCIDENCE OF HYPEREMESIS GRAVIDARUM (HG) AT SIMPANG TIGA PUBLIC HEALTH BENER MERIAH DISTRICT
}

\section{Hubungan Pengetahuan dan Sikap Ibu Hamil Pada Kejadian Hiperemesis Gravidarum (HG) di Puskesmas Simpang Tiga Kabupaten Bener Meriah}

\section{Nurlaely. H S*, Rahma Yani, Lia Muslima}

STIKes Payung Negeri Aceh Darussalam

*Alamat Korespondensi: nurlaely851@gmail.com

\begin{tabular}{l}
\hline Article Info \\
\hline Article History \\
Received: 26 Jun 2021 \\
Revised : 07 Agust 2021 \\
Accepted: 17 Agust \\
2021
\end{tabular}

Keywords :

Knowledge,

Hyperemesis

Gravidarum,

excessive naunsea

excessive.

\begin{tabular}{ll}
\hline Kata kunci : & \\
Pengetahuan & \\
Hiperemesis & \\
Gravidarum, & Mual \\
muntah & yang \\
berlebihan. &
\end{tabular}

\begin{abstract}
ABSTRAK
The maternal mortality rate in Indonesia is increasing from year to year, both during pregnancy and childbirth. One of them is Hyperemis Gravidarum, which is excessive nausea and vomiting. The number of events reaches $12.5 \%$ of the number of pregnancies in the world. This research uses descriptive analytical method with a cross sectional approach. The population is all pregnant women totaling 403 people. The sample is 80 people. The data collection technique used a questionnaire, while the sampling technique was accidental sampling which was carried out for 1 month. The analysis in this study is chi-square. The results of chi-square $\left(X^{2}\right)$ show that there is a relationship between knowledge of pregnant women and the incidence of Hyperemesis, with a value $(P$ value $=0.041<=0.05)$. And the chi-square $\left(X^{2}\right)$ results show that there is no relationship between mother's attitude and Hyperemesis Gravidarum, with a value $(P$ value $=0.428>=0.05)$, so it can be concluded that the good or bad attitude of the mother every day has no effect on the incidence of Hyperemesis Gravidarum. This research is expected to be an input for midwifery students in preventing the occurrence of Hyperemesis Gravidarum by increasing the knowledge of pregnant women through counseling carried out during field practice. With good knowledge of the mother, it will be able to reduce the occurrence of Hyperemesis Gravidarum.
\end{abstract}

\footnotetext{
Angka kematian ibu di Indonesia dari tahun ke tahun semakin meningkat, baik pada saat kehamilan dan proses persalinan. Salah satu diantaranya adalah Hiperemis Gravidarum yaitu mual muntah yang berlebihan. Jumlah kejadiannya mencapai $12,5 \%$ dari jumlah kehamilan di dunia. Penelitian menggunakan metode Deskriptif Analitik dengan pendekatan Cross Sectional. Populasi adalah seluruh ibu Hamil berjumlah 403 orang. Sampel berjumlah 80 orang. Teknik pengumpulan data menggunakan kuesioner, sedangkan teknik pengambilan sampel adalah accidental sampling yang dilakukan selama 1 bulan. Analisa dalam penelitian ini adalah chi-square. Hasil chi-square $\left(X^{2}\right)$ menunjukan ada hubungan pengetahuan ibu hamil dengan kejadian Hiperemesis, dengan nilai ( $P$ value $=0,041<\alpha=0,05)$. Dan hasil chi-square $\left(X^{2}\right)$ menunjukan tidak ada hubungan antara sikap ibu dengan Hiperemesis Gravidarum, dengan nilai ( $\mathrm{P}$ value = $0,428>\alpha=0,05)$, sehingga dapat disimpulkan baik buruknya sikap ibu sehari-hari tidak ada pengaruhnya terhadap kejadian hipermisi gravidarum. Penelitian ini diharapkan dapat menjadi sebagai bahan masukan untuk mahasiswi kebidanan dalam mencegah terjadinya Hiperemesis Gravidarum dengan meningkatkan pengetahuan ibu hamil melalui konseling yang dilakukan ketika praktik lapangan. Dengan baiknya pengetahuan ibu, maka akan dapat mengurangi terjadinya hiperemisis gravidarum.
} 


\section{PENDAHULUAN}

Berdasarkan World Health Organization (WHO) jumlah kejadian Hiperemesis Gravidarum mencapai $12,5 \%$ dari jumlah seluruh kehamilan di dunia. Mual dan muntah dapat mengganggu dan membuat ketidakseimbangan cairan pada cairan pada jaringan ginjal dan hati menjadi nekrosis (WHO, 2015).

Mual dan muntah, tanda-tanda inidikenal sebagai morning sickness dan dialami oleh sekitar $50 \%$ ibu hamil. Walaupun morning sickness lebih sering terjadi pada pagi hari tetapi mual dan muntah bisa jadi tidak mengenal waktu. Karena terjadinya perubahan berbagai hormon dalam tubuh pada awal kehamilan. Meski begitu, kondisi pada setiap ibu hamil tidak sama ada yang ringan dan ada yang berat (Saifuddin, 2016).

Mual (nausea) dan muntah (emesis gravidarum) adalah gejala yang wajar dansering terjadi pada kehamilan trimester I. Mual biasanya terjadi pada pagi hari, tetapi dapat pula timbul setiap saat dan malamhari, gejala-gejala ini kurang lebih terjadi 6 minggu setelah hari pertama haid terakhir dan berlangsung selama kurang lebih 10 minggu. Mual dan muntah terjadi pada $60-80 \%$ primigravida dan $40-60 \%$ multigravida. Satu diantara seribu kehamilan, gejala-gejala ini menjadi lebih berat. Perasaan mual disebabkan oleh meningkatnya kadar hormon estrogen dan HCG dalam serum (Manuaba, 2015).

Hasil survey awal yang diperoleh di Puskesmas Simpang Tiga Kab. Bener Meriah, didapatkan bahwa seluruh ibu hamil berjumlah 403 orang, sedangkan jumlah ibu hamil yang mengalami Hipermesis Gravidarum ringan sebanyak 42 orang (20\%). Dan data tersebut didapatkan bahwa masih banyaknya ibu hamil dengan Hipermesis gravidarum, peneliti juga melakukan wawancara dengan ibu yang mengalami Hiperemesis Gravidarum sampai mengalami penurunan berat badan drastis serta keadaan umumnya buruk sehingga perlu dirawat. Maka dari itu tujuan dari penelitihan ini adalah untuk mecari tahu apakah pengetahuan dan sikap mempengaruhi kejadian Hiperemisis gravidarum pad ibu hamil.

\section{BAHAN DAN METODE}

Penelitian ini menggunakan metode deskriptif analitik dengan pendekatan Cross Sectional. Penelitian ini telah dilakukan di Puskesmas Simpang Tiga Kabupaten Bener Meriah. Penelitian dilakukan pada Bulan November - Desember 2020. Populasi yang digunakan adalah seluruh ibu hamil yang berjumlah 403 ibu hamil. Sampel berjumlah 80 orang ibu hamil. Teknik pengambilan sampel yang digunakan adalah Accidental Sampling (Hidayat, 2017).

Teknik pengumpulan data menggunakan kuesioner. Analisis yang digunakan adalah uji statistik Chi-square. Teknik analisis yang dilakukan yaitu dengan analisa Chi-square dengan menggunakan derajat kepercayaan $95 \%$ dengan $\alpha$ $5 \%$, sehingga jika nilai $p$ ( $p$-value) 0,05 maka hasil perhitungan statistik tidak bermakna atau tidak ada hubungan antara variabel dependen dan independen (Hidayat, 2017).

\section{HASIL}

\section{Analisis Univariat}

Tabel 1. Karakteristik Ibu Hamil

\begin{tabular}{lcc}
\hline \multirow{2}{*}{ Karakteristik } & \multicolumn{2}{c}{ Responden } \\
\cline { 2 - 3 } & $\mathbf{n}$ & $\mathbf{\%}$ \\
\hline Hipermesis Gravidarum & & \\
$\quad$ Ada & 42 & 52,5 \\
$\quad$ Tidak Ada & 38 & 47,5 \\
\hline $\begin{array}{l}\text { Pengetahuan } \\
\quad \text { Baik }\end{array}$ & 18 & 22,5 \\
$\quad$ Cukup & 25 & 31,2 \\
$\quad$ Kurang & 37 & 46,2 \\
\hline Sikap & & \\
$\quad$ Positif & 31 & 38,7 \\
\hline Negatif & 49 & 61,2 \\
\hline Total & $\mathbf{8 0}$ & $\mathbf{1 0 0}$ \\
\hline
\end{tabular}

Sumber: Data Primer, 2019

Berdasarkan tabel di atas dapat dilihat bahwa dari 80 (100\%) responden, mayoritas Hiperemesis Gravidarum yaitu sebanyak 42 
responden $(52,5 \%)$, mayoritas berpengetahuan kurang sebanyak 37 responden $(46,25 \%)$ dan mayoritas bersikap negatif tentang Hiperemesis
Gravidarum yaitu sebanyak 49 responden $(61,25 \%)$.

\section{Analisa Bivariat}

Tabel 2. Hubungan antara Variabel Independen dengan Kejadian Hiperemisis Gravidarum

\begin{tabular}{|c|c|c|c|c|c|c|c|}
\hline \multirow{3}{*}{ Variabel } & \multicolumn{4}{|c|}{ Hiperemesis Gravidarum } & \multirow{2}{*}{\multicolumn{2}{|c|}{ Total }} & \multirow{3}{*}{$\begin{array}{c}\mathrm{P} \\
\text { Value }\end{array}$} \\
\hline & \multicolumn{2}{|c|}{ Ada } & \multicolumn{2}{|c|}{ Tidak Ada } & & & \\
\hline & $\mathbf{n}$ & $\%$ & n & $\%$ & $\mathbf{n}$ & $\%$ & \\
\hline \multicolumn{8}{|l|}{ Pengetahuan } \\
\hline Baik & 12 & 15 & 6 & 7,5 & 18 & 100 & \multirow{3}{*}{0,041} \\
\hline Cukup & 8 & 10 & 17 & 21,2 & 25 & 100 & \\
\hline Kurang & 22 & 27,5 & 15 & 18,7 & 37 & 100 & \\
\hline \multicolumn{7}{|l|}{ Sikap } & \multirow{3}{*}{0,428} \\
\hline Positif & 18 & 22,5 & 13 & 16,2 & 30 & 100 & \\
\hline Negatif & 24 & 30 & 25 & 31,2 & 50 & 100 & \\
\hline
\end{tabular}

Berdasarkan Tabel 2 dapat dilihat dari 80 responden (100\%) yang berpengetahuan baik, ibu dengan Hiperemesis Gravidarum sebanyak 12 orang (15\%) dan responden yang berpengetahuan baik tetapi tidak mengalami Hiperemesis Gravidarum sebanyak 6 orang (7,5\%). Responden yang berpengetahuan cukup dan ada yang mengalami Hiperemesis Gravidarum yaitu sebanyak 8 responden (10\%) dan responden yang berpengetahuan cukup tapi tidak Hiperemesis Gravidarum sebanyak 17 orang (21,25\%). Sedangkan responden yang berpengetahuan kurang dan ada mengalami Hiperemesis Gravidarum yaitu sebanyak 22 (27,5\%) dan $r$ esponden yang berpengetahuan kurang tapi tidak Hiperemesis Gravidarum sebanyak 15 orang $(18,75 \%)$.

Berdasarkan hasil uji statistik dengan chisquare antara variabel pengetahuan ibu tentang Hiperemesis Gravidarum dengan variabel diperoleh nilai $P$ Value $0,041(<0,05)$ yang artinya ada hubungan antara pengetahuan ibu tentang Kejadian Hiperemesis Gravidarum di Puskesmas Simpang Tiga.

Berdasarkan tabel 2 dapat dilihat dari 80 responden $(100 \%)$ yang mempunyai sikap positif dan ada mengalami Hipermesis Gravidarum yaitu sebanyak 18 orang $(22,5 \%)$ dan responden yang mempunyai sikap positif tetapi tidak Mengalami Hipermesis Gravidarum sebanyak 13 orang $(16,25 \%)$. Sedangkan responden yang mempunyai sikap negatif dan ada mengalami Hipermesis Gravidarum sebanyak 24 orang (30\%) dan responden yang mempunyai sikap negatif tetapi tidak Hipermesis Gravidarum sebanyak 25 orang $(31,25 \%)$.

Berdasarkan hasil uji statistik dengan chisquare antara variabel sikap ibu tentang Hiperemesis Gravidarum diperoleh nilai $P$ Value $0,428(>0,05)$ yang artinya tidak ada hubungan antara sikap ibu dengan Kejadian Hiperemesis Gravidarum di Puskesmas Simpang Tiga.

\section{PEMBAHASAN}

Setelah dilakukannya penelitian terhadap 80 orang ibu di Puskesmas Simpang Tiga maka dapat dilakukan pembahasan sebagai berikut:

Ibu Hamil Pada Kejadian hiperemesis
Gravidarum
Berdasarkan analisa univariat didapat
bahwa mayoritas adamengalami Hiperemesis
Gravidarum yaitu sebanyak 42 responden (52,5\%)
dan minoritas tidak ada Hiperemesis Gravidarum


yaitu sebanyak 38 responden (47,5\%). Hal ini menunjukan bahwa kebanyakan ibu mengalami Hiperemesis Gravidarum.

Hipermesis Gravidarum adalah mual muntah yang berlebihan yang terjadi pada awal kehamilan sampai umur 20 minggu. Keluhan muntah kadang-kadang begitu hebat dimana segala apa yang dimakan dan diminum dimuntahkan sehingga dapat mempengaruhi keadaan umum (Saifudin, 2016).

Menurut asumsi peneliti bahwa dari penelitian ini masih banyak ibu yang mengalami kejadian Hiperemesis Gravidarum, hasil ini berdasarkan wawancara dan kuesioner yang telah dibagikan.

\section{Pengetahuan Ibu Tentang Hiperemisis Gravidarum}

Berdasarkan hasil penelitian menunjukkan bahwa mayoritas pengetahuan ibu adalah kurang yaitu $46,25 \%$ sisanya berpengetahuan cukup $31,25 \%$ dan berpengetahuan baik $46,25 \%$.

Pengetahuan (knowledge) adalah sesuatu yang hadir dan terwujud dalam jiwa dan pikiran seseorang karena adanya reaksi, persentuhan dan hubungan dengan lingkungan sekitarnya. Pengetahuan ini meliputi emosi, tradisi, ketrampilan, informasi, akidah dan pikiran-pikiran (Notoadmodjo, 2017).

Pengetahuan ibu yang kurang tentang Hiperimis gravidarum dapat mengakibat terganggunya proses kehamilan ibu. Karena ibu tidak tidak tahu apa tanda dan gejala hipremisis tersebut dan penanganan pertama yang harus dilakukan jika hal tersebut pada dirinya. Hal ini menunjukan bahwa kebanyakan ibu masih memiliki pengetahuan yang kurang tentang Hiperesmis Gravidarum.

Penelitian ini sejalan dengan yang dilakukan Wa Janaria Rumbia tahun 2017 di Palu Sulawesi Tengah. Hasil penelitian didapatkan bahwa pengetahuan ibu tentang Hiperemisis Gravidarum di Palu masih dalam katagori kurang, sehingga banyak ibu hamil di daerah tersebut yang tidak tau tanda dan gejala serta penanganan hiperemisis gravidarum tersebut.
Kemudian penelitian ini juga sejalan dengan yang dilakukan oleh Effendi Situmorang tahun 2016 di Medan. Peneliti menemukan masih kurangnya pengetahuan ibu tentang hiperimis gravidarum dan menganggap sepele hal tersebut.

\section{Sikap Ibu Tentang Hiperemesis Gravidarum}

Berdasarkan analisa univariat didapatkan bahwa mayoritas responden yang mempunyai sikap positif tentang Hiperesmis Gravidarum yaitu sebanyak 31 Responden (38,75\%) dan manoritas responden yang mempunyai sikap negatif tentang Hiperemesi Gravidarum yaitu sebanyak 49 Responden (61,25\%). Hal ini menunjukan bahwa kebanyakan ibu masih memiliki sikap yang negatif tentang Hiperesmis Gravidarum.

Hasil Penelitian ini Sejalan dengan penelitian yang dilakukan oleh Wawan 2018 di Puskesmas Padalarang. Hasil penelitian didapatkan ibu yang memiliki sikap positif dan 47 responden $(45,2 \%)$ dan ibu yang memiliki sikap negatif 57 responden $(54,8 \%) 104$ responden.

Pengertian sikap adalah pernyataan evaluatif terhadap objek, orang, atau peristiwa. Hal ini mencerminkan sikap seseorang terhadap sesuatu. Sementara itu, pengertian lain dari sikap menurut (Notoatmodjo, 2017) adalah reaksi atau respon yang masih tertutup terhadap stimulus atau objek.

\section{Hubungan Pengetahuan Dengan Hiperemesis Gravidarum}

Hasil uji chi-square derajat kepercayaan $95 \%$ menghasilkan $P$ Value $0,041(P<0,05)$. Hal ini menunjukan bahwa ada hubungan antara pengetahuan ibu dengan kejadian Hiperemisis Gravidarum. Sehingga perlu dilakukan peningkatan pengetahuan ibu di Puskesmas Simpang Tiga.

Hasil penelitian ini sejalan dengan yang dilakukan Wa Janaria Rumbia tahun 2017 di Puskesmas Puuwatu Kota Kendari. Hasil penelitian menunjukan analisa bivariat didapatkan $p$ value $=0,014 \quad(p<0,05)$ bahwa secara statistic ada hubungan antara pengetahuan dengan Hiperemesis Gravidarum. 
Menurut asumsi peneliti bahwa dari penelitian ini masih banyak ibu yang berpengetahuan kurang dan mengalami Hiperemesis Gravidarum.

\section{Hubungan Sikap Dengan Kejadian Hiperemesis Gravidarum}

Hasil uji chi-square derajat kepercayaan $95 \%$ menghasilkan $\mathrm{P}$ Value $0,428(>0,05)$. Hal ini menunjukan bahwa secara statistik tidak ada hubungan antara sikap dengan kejadian Hiperemesis Gravidarum di Puskesmas Simpang Tiga.

Hasil penelitian ini sejalan dengan yang dilakukan Siti Mudlika (2019) di Puskesmas Sumobito Kota Jombang. Berdasarkan hasil penelitian tentang sikap didapatkan hasil bahwa sikap tidak ada hubungannya dengan kejadian hiperemisis gravidarum. Ini terbukti dari uji statistic yang diperoleh nilai $P$ Value $<0,05$. Maka dari itu sikap ibu tidak ada pengaruhnya terhadap kejadian hiperimisis gravidarum.

Menurut asumsi peneliti bahwa dari penelitian ini masih banyak ibu yang memiliki sikap negatif dan tidak mengalami Hiperemesis Gravidarum.

\section{KESIMPULAN DAN SARAN}

Berdasarkan hasil penelitian tentang Hubungan Tingkat Pengetahuan Ibu Hamil Pada Kejadian Hiperemesis Gravidarum di Puskesmas Simpang Tiga dapat disimpulkan bahwa ada hubungan antara pengetahuan ibu tentang Kejadian Hiperemesis Gravidarum, karena diperoleh nilai $P$ Value $0,041(<0,05)$. Sehingga kedepannya di Puskesmas perlu dilakukan peningkatan pengetahuan ibu tentang hiperemisis gravidarum. Kemudian tidak ada hubungan antara sikap ibu dengan Kejadian Hiperemesis Gravidarum, karena diperoleh nilai $P$ Value $0,428(>0,05)$.

Semoga dengan ada penelitian ini dapat memberikan pengetahuan kepada ibu hamil tentang tanda dan gejala, penanganan serta pencegahannya. Agar kedepannya kejadian hiperemisis ini dapat berkurang. Dan semoga penelitian ini dapat sebagai masukan kepada tenaga kesehatan agar lebih meningkatkan mutu pelayanan kesehatan dengan memberikan penanganan dan konseling yang tepat kepada ibu yang mengalami hiperemisis gravidarum.

\section{DAFTAR PUSTAKA}

Hidayat A. Metode penelitian kebidanan dan teknik analisis data. 2017;

Kuntoro W. Kepuasan pasien terhadap kualitas pelayanan di tempat pendaftaran pasien rawat jalan Puskesmas Kretek Bantul Yogyakarta. J Kesehat Vokasional. 2016;2(1):140-7.

Kementerian Kesehatan RI. Angka Kematian Ibu [Internet]. 2015 [cited 2016 Mar 6]. Available from:

http://www.kompasiana.com/kadirsaja/catata n-menjelang-2014-angkakematian-ibumeningkat_552fdb636ea83469518b45e0

Manuaba IBG. IImu kebidanan, penyakit kandungan \& keluarga berencana untuk pendidikan bidan. In Jakarta: Egc; 2015.

Maulana M. Penyakit Kehamilan dan Pengobatannya. Vol. 20. Yogyakarta; 2013. 40-3 p.

Mudlika, Siti. Hubungan Pengetahuan dan Sikap Dengan Hiperimisis Gravidarum di Puskesmas Sumobito tahun 2019 [Skripsi]: Universitas Pesantren Tinggi Darul ‘Ulum; 2019.

Notoatmodjo S. Metodologi penelitian kesehatan. Jakarta: PT. Rineka Cipta; 2017.

Riwidikdo H. Statistik Kesehatan. Yogyakarta: mitra cendikia; 2014.

Rukiyah, Yulianti. Asuhan Kebidanan Patologi Kebidanan. Jakarta: Trans Info Media; 2014.

Rumbia, Wa Janaria. Hubungan Pengetahuan Ibu Hamil Dengan Kejadian Hiperemisis Gravidarum di Palu tahun 2017 [Skripsi]: Universitas Tadulako; 2017.

Saifuddin B. Buku Panduan Praktis Pelayanan Kesehatan Maternal dan Neonatal. Jakarta: yayasan bina pustaka sarwono prawirahardjo; 
2016.

Situmorang, Effendi. Hubungan Pengetahuan dan Sikap Terhadap Angka Kejadian Hiperimisis di Medan Tahun 2016 [Skripsi]: Universitas Muhammadiyah Medan; 2016.

Wawan. Pengaruh Sikap Bumil Terhadap Hiperimisis Gravidarum di Puskesmas
Padalarang tahun 2018 [Skripsi]: Universitas Padalarang; 2018.

Wiknjosastro, Hanifa. Ilmu Kebidanan. Edisi ke-3. Jakarta: Yayasan Bina Pustaka Sarwono Prawirohardjo; 2014.

World Health Organization (WHO). data in 2015 Hiperemesis gravidarum. 2015 